\title{
Gambaran histopatologik mukosa laring tikus wistar yang dipapar asap rokok, obat nyamuk bakar, dan kendaraan bermotor
}

\author{
${ }^{1}$ Holy Poluan \\ ${ }^{2}$ Carla F. Kairupan \\ ${ }^{2}$ Meilany Durry
}

\author{
${ }^{1}$ Kandidat Skripsi Fakultas Kedokteran Universitas Sam Ratulangi Manado \\ ${ }^{2}$ Bagian Patologi Anatomi Fakultas Kedokteran Universitas Sam Ratulangi Manado \\ 2Email:holylouis15@gmail.com
}

\begin{abstract}
Air polution is a condition where the air is contaminated with chemicals, particles/matters and other biological substances such as cigarette smoke, mosquito coil smoke, and exhaust gas. Cigarette smoke, mosquito coil smoke and exhaust gas contain substances that can cause inflammation, hyperresponsivity, obstruction, and metaplasia of the respiratory tract. This study aimed to compare the exposure effect of cigarette smoke, mosquito coil smoke, and exhaust gas on the histopathological features of Wistar rat larynx. This was an experimental laboratory study. Subjects were 20 rats divided into 4 groups; Group I, the negative control group, and 3 treatment groups (Group II, III, and IV). Group II was exposed by cigarette smoke, group III was exposed by mosquito coil smoke, and group IV was exposed by exhaust gas. Subjects were put in a modified exposure cage in according with the treatment groups and were exposed for 2 hours per day for 30 days. The results showed that inflammatory cells were found the most in group 4, meanwhile in group II were the least. Metaplasia occured the most in group II, menwhile group III and IV had similar results. In general, group IV showed the worst pathological reaction, followed by group III and group II. Conclusion: Histopathological feature of larynx of wistar rat exposed by exhaust gas showed the worst histopathological changes, followed by mosquito coil smoke exposure group and cigarette smoke group.

Keywords: cigarette smoke, mosquito coil smoke, exhaust gas, larynx histopathological feature, inflammatory cells, metaplasia
\end{abstract}

\begin{abstract}
Abstrak: Polusi udara adalah suatu kondisi dimana udara tercemari oleh bahan kimia, zat/partikel dan bahan biologis lainnya.Asap rokok, asap obat nyamuk dan asap kendaraan bermotor merupakan contoh polusi udara. Asap rokok, asap obat nyamuk dan asap kendaraan bermotor mengandung zat yang dapat menyebabkan peradangan, hiperresponsivitas, obstruksi dan metaplasia saluran pernapasan. Penelitian ini bertujuan untukmembandingkan pengaruh paparan asap rokok, asap obat nyamuk dan asap kendaraan bermotor terhadap gambaran histopatologik laring tikus wistar. Jenis penelitian ini ialah eksperimental laboratorik. Penelitian ini menggunakan 20 ekor tikus yang dibagi dalam 4 kelompok: 1 kelompok kontrol negatif (kelompok I) dan 3 kelompok perlakuan (kelompok II, III, IV). Kelompok II dipaparkan asap rokok, kelompok III dipaparkan asap obat nyamuk bakar dan kelompok IV dipaparkan asap kendaraan bermotor. Subjek penelitian kelompok perlakuan diletakkan di kandang perlakuan yang telah dimodifikasi menurut kelompok perlakuan dan diberi paparan asap selama 2 jam per hari selama 30 hari. Hasil penelitian menunjukkan bahwa jumlah sel radang paling banyak terdapat pada kelompok IV, dan paling sedikit pada kelompok II. Metaplasia yang terjadi paling banyak terdapat pada kelompok II sedangkan kedua kelompok III dan IV memiliki jumlah yang hampir sama. Secara umum kelompok IV menunjukkan reaksi patologik laring yang paling jelek, diikuti oleh kelompok III dan kelompok II. Simpulan: Gambaran histopatologik laring tikus wistar yang dipapar asap kendaraan bermotor menunjukkan perubahan histopatologik yang paling jelek, diikuti yang dipapar dengan asap obat nyamuk bakar dan asap rokok.
\end{abstract}

Kata kunci: asap rokok, asap kendaraan bermotor, asap obat nyamuk, gambaran histopatologik laring, sel radang, metaplasia 
Poluan, Kairupan, Durry: Gambaran Hispatologik mukosa...

Polusi udara adalah suatu kondisi dimana udara tercemari oleh bahan kimia, zat/partikel dan bahan biologis lain yang bisa membahayakan kesehatan manusia serta mahluk hidup lainnya. ${ }^{1}$ Polusi udara terbagi atas polusi udara dalam-ruang dan polusi udara luar-ruang. ${ }^{2}$ Asap rokok dan asap obat nyamuk merupakan contoh polusi udara dalam-ruang, sedangkan polusi udara luar-ruang dapat berupa asap kendaraan bermotor.

Asap rokok mengandung zat yang memiliki efek iritan langsung pada saluran pernapasan, menyebabkan peradangan dan meningkatkan produksi lendir. ${ }^{2}$ World Health Organization (WHO) melaporkan bahwa pada tahun 2012 terdapat sekitar $21 \%$ perokok yang berumur di atas 15 tahun dari total populasi global. ${ }^{4}$

Asap obat nyamuk bakar mengandung sejumlah besar partikel submikrometer yang dapat meningkatkan responsivitas jalan nafas dan formaldehid yang mengakibatkan terjadinya obstruksi jalan nafas. ${ }^{5,6}$ Menurut data WHO obat nyamuk bakar merupakan pilihan bagi masyarakat kelas menengah ke bawah. ${ }^{7}$

Dibandingkan dengan kedua gas sebelumnya, gas kendaraan bermotor mengandung kombinasi dari banyak gas seperti $\mathrm{N}_{2}, \mathrm{CO}_{2}, \mathrm{CO}, \mathrm{H}_{2} \mathrm{O}$, dan $\mathrm{O}_{2} .{ }^{8}$ Gas yang paling berbahaya diantaranya ialah karbon monoksida (CO). Gas ini memiliki potensi untuk membahayakan nyawa manusia dan hewan jika terpapar pada konsentrasi yang tinggi. ${ }^{9}$ Sebuah industri otomotif global (OICA) melaporkan sekitar 1/6 penduduk dunia menggunakan kendaraan bermotor. ${ }^{10}$

Studi terbaru menemukan bahwa particulate matter (PM) asap dari sekeping obat nyamuk bakar sama bahayanya dengan 75-137 batang rokok. ${ }^{11}$ Di samping itu, sebuah penelitian yang lain membuktikan bahwa asap rokok lebih berbahaya dibandingkan asap kendaraan bermotor karena rokok memproduksi 10 kali lebih banyak emisi PM dibandingkan kendaraan bermotor. $^{12}$ Penelitian yang dilakukan ini bertujuan untuk membandingkan pengaruh paparan asap rokok, asap obat nyamuk dan asap kendaraan bermotor terhadap gambaran histopatologik laring tikus wistar.

\section{METODE PENELITIAN}

Jenis penelitian ini ialah eksperimental laboratorik. Penelitian dilakukan di LaboratoriumRiset Biomedik dan Patologi Anatomi Fakultas Kedokteran Universitas Sam Ratulangi Manado pada bulan Oktober 2015 sampai Januari 2016. Subjek penelitian ialah 20 tikus Wistar spesies Rattus norvegicus berumur 4-5 bulan dengan berat rata-rata 150-200 gram. Tikus Wistar dibagi menjadi 4 kelompok, masing-masing terdiri dari 5 ekor tikus. Kelompok I merupakan kelompok kontrol negatif, tidak diberikan paparan apapun selama 30 hari. Kelompok II diberi paparan asap rokok selama 2 jam per hari selama 30 hari. Kelompok III diberi paparan asap obat nyamuk bakar selama 2 jam per hari selama 30 hari. Kelompok IV merupakan kelompok perlakuan yang diberi paparan asap kendaraan bermotor selama 2 jam per hari selama 30 hari. Semua hewan uji diterminasi pada hari ke-31.

Asap rokok yang diberikan berasal dari emisi hasil pembakaran batang rokok. Satu batang rokok memerlukan waktu \pm 10 menit untuk habis terbakar, sehingga untuk memroduksi emisi asap yang dapat bertahan terus-menerus selama 120 menit diperlukan sebanyak \pm 12 batang rokok. Obat nyamuk yang diberikan disesuaikan dengan waktu perlakuan, yaitu untuk perlakuan selama 120 menit dibutuhkan kira-kira satu per empat panjang coil obat nyamuk bakar. Asap kendaraan bermotor yang diberikan sesuai dengan volume kantong yang menampung asap tersebut diberikan selama 120 menit per hari. Satu kantong plastik yang digunakan memiliki volume $\pm 70,68 \mathrm{~m}^{3}$.

\section{Pemaparan Asap Rokok}

Asap rokok dipaparkan dengan cara meletakkan hewan uji dalam kandang tertutup yang telah diberi lubang untuk pemberian asap dan lubang untuk ventilasi. Rokok dinyalakan dan dimasukkan dalam 
lubang untuk pemberian asap. Asap rokok memenuhi kandang perlakuan sehingga tikus yang berada di dalamnya terpapar asap rokok (Gambar 1).

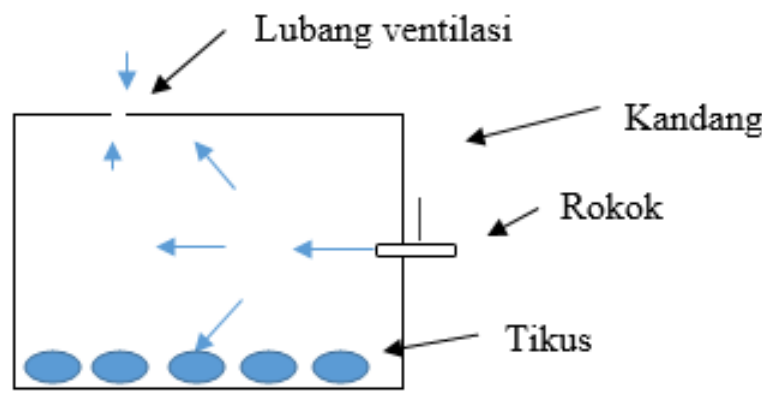

Gambar 1. Cara pemaparan asap rokok

\section{Pemaparan Asap Obat Nyamuk}

Asap obat nyamuk dipapar dengan cara meletakkan hewan uji dalam kandang tertutup yang hanya memiliki satu lubang untuk ventilasi. Obat nyamuk dinyalakan dan diletakkan dalam kandang tersebut (Gambar 2).

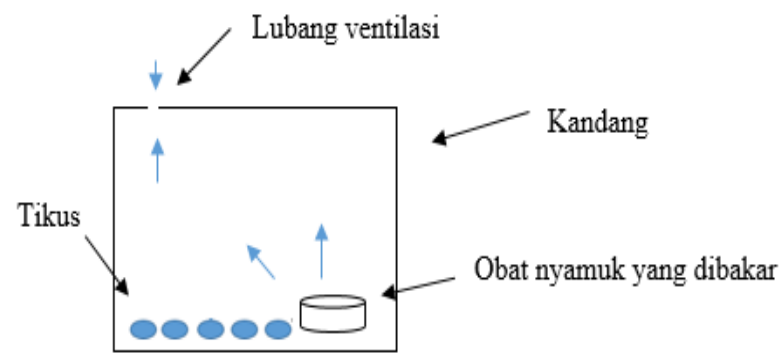

Gambar 2. Cara pemaparan obat nyamuk bakar

\section{Pemaparan Asap Kendaraan Bermotor}

Asap kendaraan bermotor dipaparkan dengan cara meletakkan hewan uji dalam kandang tertutup yang telah diberi lubang untuk pemberian asap dan lubang untuk ventilasi. Mobil dinyalakan kemudian asap yang dihasilkan diambil dengan menggunakan kantong plastik yang sudah diberi lubang untuk pemberian asap di bagian belakang. Pada lubang tersebut sudah dimasukkan sedotan yang diberi penutup untuk mencegah pengeluaran kembali asap yang sudah masuk. Sedotan tersebut digunakan sebagai media penghubung antara kantong dan kandang. Ujung knalpot dimasukkan ke dalam kantong. Karena permukaan knalpot yang panas, maka knalpot diberi pembungkus terlebih dahulu (Gambar 3.1). Setelah kantong penuh, kantong diikat di depan terlebih dahulu sebelum dilepas dari knalpot (Gambar 3.2). Setelah dilepas, kantong tersebut dihubungkan dengan kandang melalui sedotan yang telah dibuka penutupnya (Gambar 3.3). Untuk mempertahankan tingkat kejenuhan asap dalam kantong tersebut, maka pada kantong diberikan tekanan manual. Kantong diganti dengan kantong yang masih jenuh dengan asap setelah kantong sebelumnya sudah dianggap tidak jenuh.

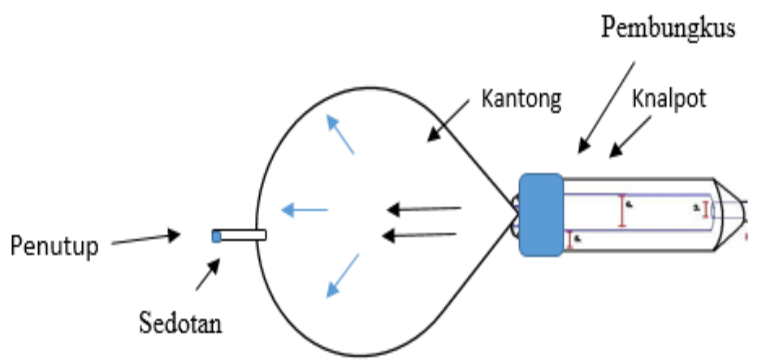

Gambar 3.1 Cara pengisian kantong

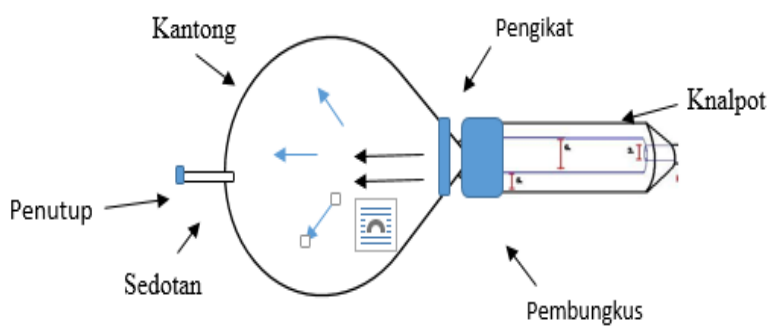

Gambar 3.2 Cara pelepasan kantong dari knalpot

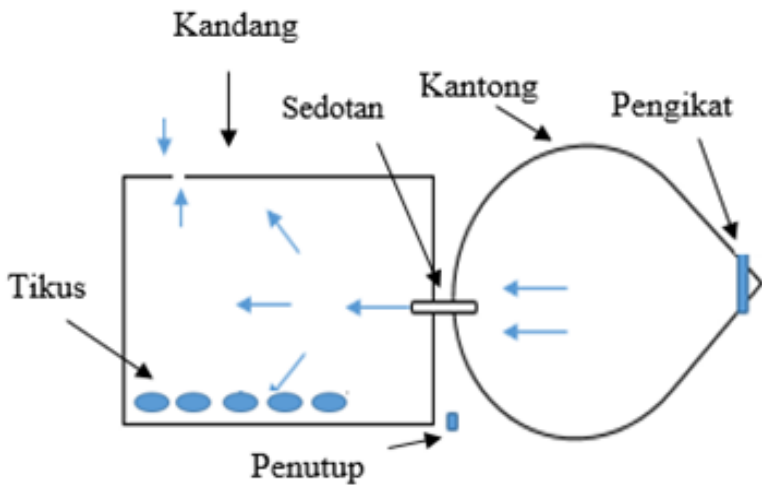

Gambar 3.3 Cara pemaparan asap kendaraan bermotor 


\section{HASIL PENELITIAN \\ Kelompok I}

Tikus wistar kelompok I merupakan kontrol negatif. Pada tikus wistar kelompok ini didapatkan laring yang sebagian besar lapisan mukosanya dilapisi oleh sel epitel kolumnar bersilia dan sisanya dilapisi oleh sel epitel gepeng berlapis (Gambar 4.1). Selain itu, ditemukan juga sedikit sel-sel radang limfosit pada lapisan mukosa (Gambar 4.2).

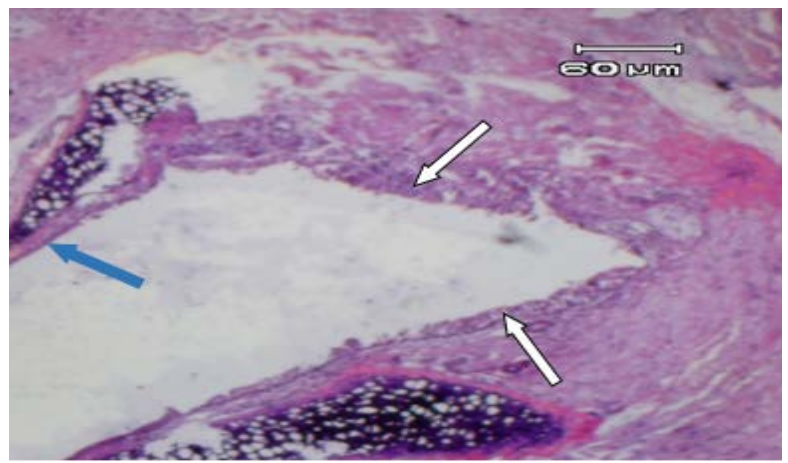

Gambar 4.1 Gambaran mikroskopik laring tikus wistar kelompok I. Lapisan sel epitel kolumnar (panah putih) dan epitel gepeng berlapis (panah biru)

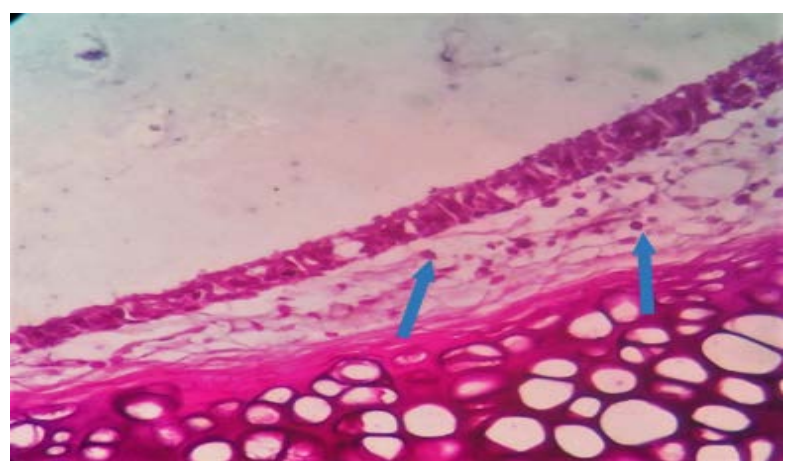

Gambar 4.2 Gambaran mikroskopik laring tikus wistar kelompok I (kontrol negatif). Sel radang limfosit (panah biru)

\section{Kelompok II}

Tikus wistar kelompok II merupakan kelompok yang dipapar asap rokok. Pada kelompok ini didapatkan laring yang hampir seluruh lapisan mukosanya dilapisi oleh epitel gepeng berlapis dan sebagian kecil oleh epitel kolumnar bersilia (Gambar 5.1). Pada kelompok ini ditemukan juga sel-sel radang limfosit pada lapisan mukosa dan submukosa (Gambar 5.2)
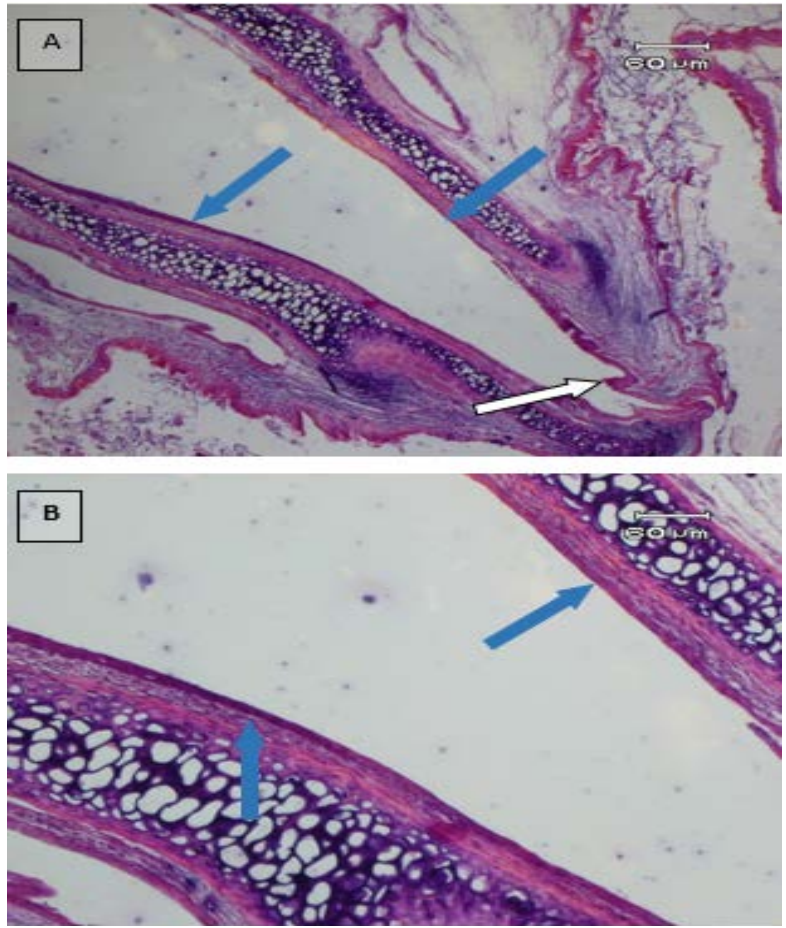

Gambar 5.1 Gambaran mikroskopis laring tikus wistar kelompok II.Lapisan sel epitel gepeng berlapis (panah biru) dan sel epitel kolumnar (panah putih)

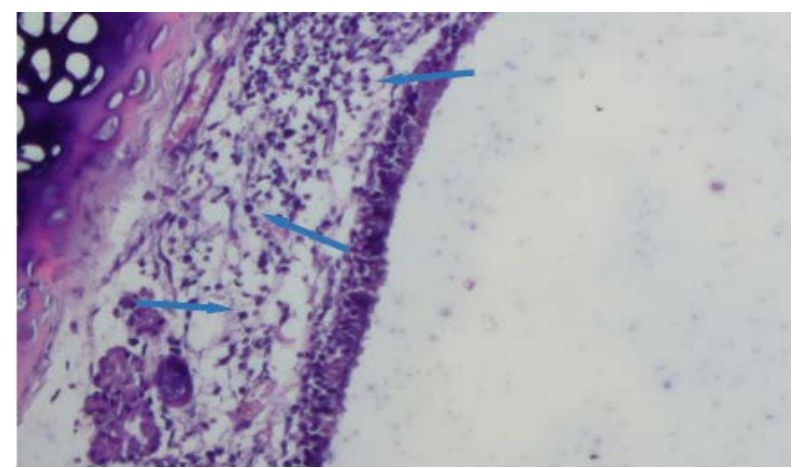

Gambar 5.2 Gambaran mikroskopis laring tikus wistar kelompok II. Sel radang limfosit (panah biru)

\section{Kelompok III}

Tikus wistar kelompok III merupakan kelompok perlakuan asap obat nyamuk bakar. Pada kelompok ini didapatkan lapisan mukosa laring yang sebagian besar dilapisi oleh epitel gepeng berlapis dan beberapa bagian kecil oleh epitel kolumnar (Gambar 6.1). Pada lapisan mukosa dan submukosa ditemukan sel-sel radang dalam jumlah yang banyak, lebih banyak dari yang terlihat pada kelompok II (Gambar $6.2)$. 

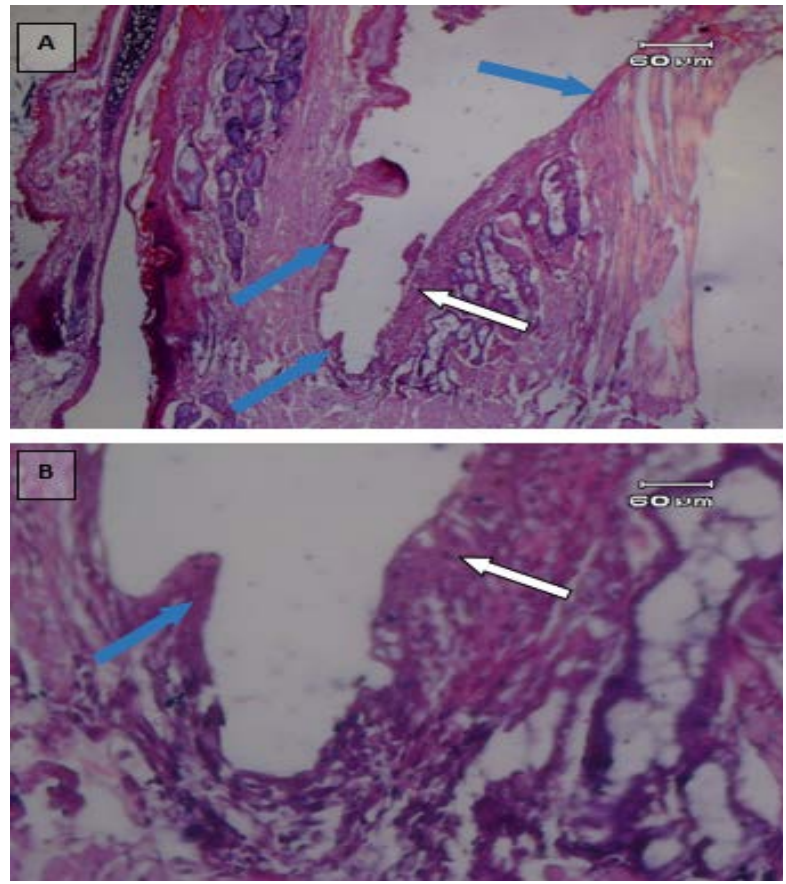

Gambar 6.1 Gambaran mikroskopis laring tikus wistar kelompok III. Lapisan sel epitel gepeng berlapis (panah biru) dan lapisan sel epitel kolumnar (panah putih).

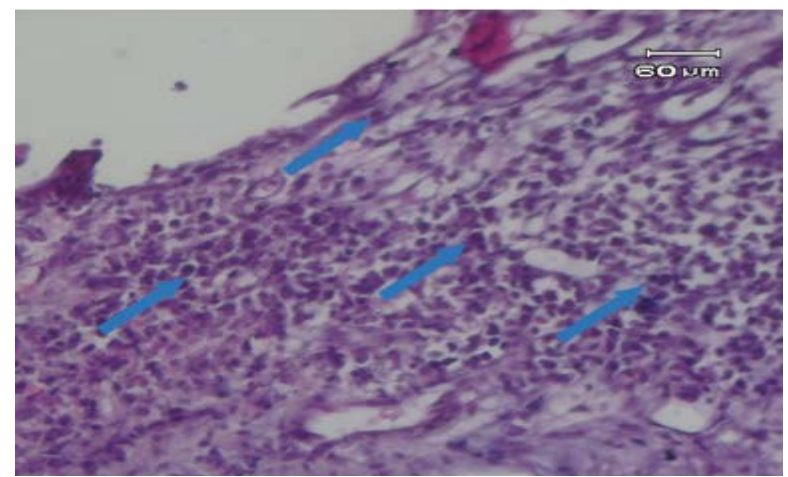

Gambar 6.2 Gambaran mikroskopis laring tikus wistar kelompok III. Sel-sel radang (panah biru).

\section{Kelompok IV}

Tikus wistar kelompok IV merupakan kelompok perlakuan asap kendaraan bermotor. Pada kelompok ini didapatkan lapisan mukosa laring yang sebagian besar dilapisi oleh sel epitel gepeng berlapis dan di beberapa tempat oleh sel epitel kolumnar (Gambar 7.1). Juga ditemukan sel-sel radang dalam jumlah yang sangat banyak pada lapisan mukosa dan submukosa, lebih banyak dari yang terlihat pada kelompok III. (Gambar 7.2).
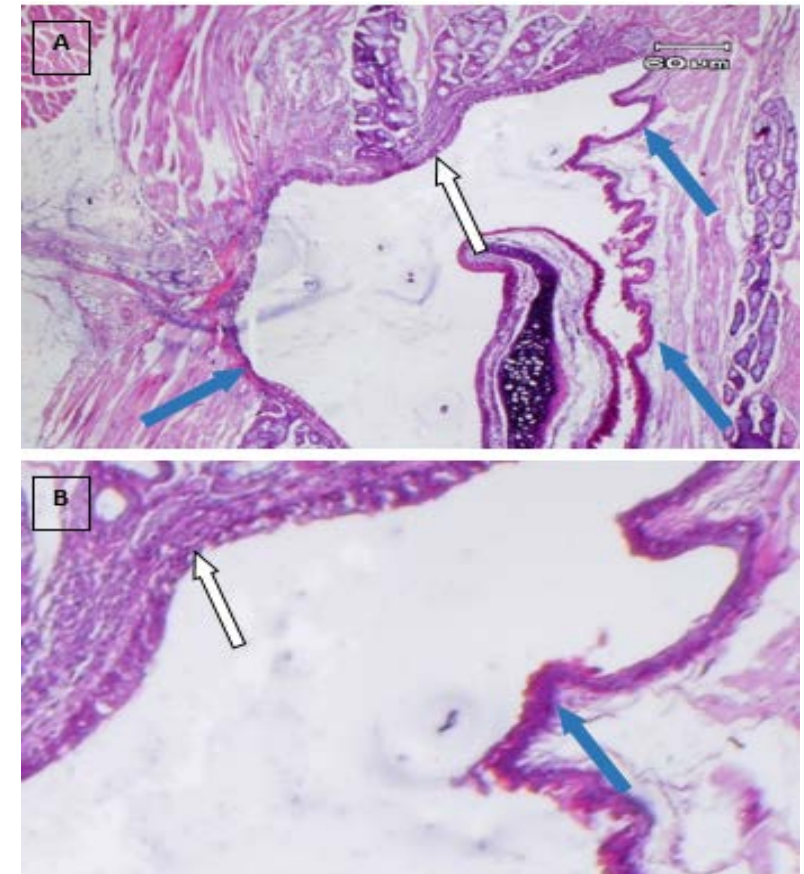

Gambar 7.1 Gambaran mikroskopis laring tikus wistar kelompok IV. Lapisan sel epitel gepeng berlapis (panah biru) dan lapisan sel epitel kolumnar (panah putih).

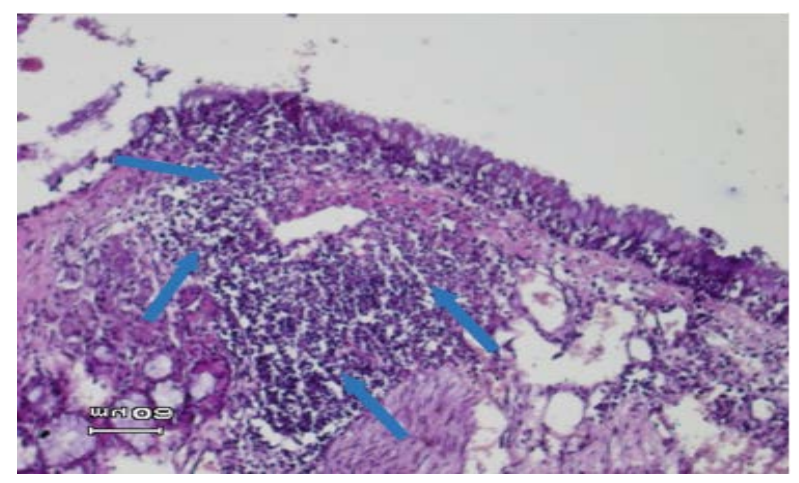

Gambar 7.2 Gambaran mikroskopis laring tikus wistar kelompok IV. Sel-sel radang (panah biru).

Perbandingan jumlah sel radang dan metaplasia skuamous antar kelompok hewan uji dapat dilihat pada Tabel 1.

\section{BAHASAN}

Pada saluran pernapasan atas, lapisan epitel merupakan lini pertahanan pertama melawan berbagai agen invasif (polutan, alergen dan mikroorganisme). ${ }^{13}$ Asap rokok, asap obat nyamuk dan asap kendaraan bermotor mengandung polutanpolutan hasil pembakaran tidak lengkap dari bahan hidrokarbon yaitu PAHs 
(polycyclic aromatic hydrocarbon), karbon monoksida, karbon dioksida dan oksidaoksida nitrogen. ${ }^{14-17}$

Tabel 1. Perbandingan perubahan histopatologik antar kelompok hewan uji

\begin{tabular}{ccc}
\hline Kelompok & $\begin{array}{c}\text { Jumlah sel } \\
\text { radang }\end{array}$ & Metaplasia \\
\hline $\begin{array}{c}\text { Kelompok I } \\
\text { (Kontrol) }\end{array}$ & + & - \\
Kelompok II & ++ & ++++ \\
(Asap Rokok) & & \\
Kelompok III & +++ & +++ \\
(Asap Obat & & \\
Nyamuk) & & \\
Kelompok IV & +++ & ++ \\
(Asap Kendaraan & & \\
Bermotor) & & \\
\hline
\end{tabular}

Keterangan

$+\quad$ : Sangat sedikit

$+\quad$ : Sedikit

++ : Banyak

++++ : Sangat banyak

Kontak dengan agen-agen invasif ini dapat menyebabkan berbagai reaksi morfologik epitel dari saluran pernapasan, seperti hiperplasia, metaplasia, penebalan submukosa dan reaksi inflamasi. Particulate matter yang dikandung oleh ketiga asap tersebut juga dapat terdeposit di saluran pernapasan dan menyebabkan hiperesponsvitas. ${ }^{13,18,19}$ Penelitian yang dilakukan ini memberikan data mengenai gambaran mikroskopik laring tikus wistar yang dipapar asap rokok, asap obat nyamuk bakar dan asap kendaraan bermotor dan perbandingan antara ketiga paparan asap tersebut.

Pada kelompok kontrol (kelompok I), gambaran mikroskopik laring menunjukkan lapisan mukosa yang sebagian besar tersusun oleh epitel kolumnar bersilia dan di beberapa tempat oleh epitel gepeng berlapis. Susunan lapisan epitel ini merupakan gambaran histologik normal dari lapisan epitel mukosa laring. ${ }^{20}$ Kelompok ini juga menunjukkan adanya sedikit sel radang limfosit pada lapisan mukosa laring. Sel-sel radang dalam jumlah sedikit ditemukan pada laring normal karena dalam udara yang dihirup terdapat juga bahan-bahan atau zat-zat yang bisa bersifat iritatif terhadap saluran pernapasan.

Pada gambaran mikroskopik laring tikus wistar kelompok perlakuan (kelompok II,III,IV) terlihat perubahan mofologik dari susunan epitel mukosa laring bila dibandingkan dengan kelompok kontrol. Lapisan epitel mukosa tampak didominasi oleh sel-sel epitel gepeng berlapis; hal ini menunjukkan bahwa telah terjadi diferensiasi epitel kolumnar bersilia ke epitel gepeng berlapis atau metaplasia skuamous. Metaplasia ini terjadi sebagai respon sel terhadap cedera atau iritasi terusmenerus oleh polutan yang dipaparkan. Epitel kolumnar bersilia tidak dapat bertahan dari bahan-bahan kimia iritatif yang dikandung oleh polutan sehingga terjadi diferensiasi ke epitel gepeng berlapis yang lebih mampu bertahan terhadap bahan iritatif. $^{21}$

Dilihat dari infiltrasi sel-sel radang, kelompok perlakuan (kelompok II,III,IV) memiliki sel-sel radang yang lebih banyak dibandingkan dengan kelompok kontrol. Pada kelompok perlakuan terlihat banyak sel radang limfosit dan beberapa sel PMN (polimorfonuklear). Banyaknya sel radang limfosit menunjukkan telah terjadinya inflamasi kronik di lapisan epitel laring. Inflamasi kronik ini terjadi karena perlakuan yang diberikan secara intermitten (2 jam per hari dalam waktu 30 hari), namun tidak dihentikan selama 30 hari sehingga inflamasi akut yang terjadi belum sepenuhnya hilang ketika paparan kembali diberikan. Inflamasi yang terjadi adalah suatu respons protektif yang ditujukan untuk menghilangkan penyebab awal cedera sel serta membuang sel dan jaringan nekrotik yang diakibatkan oleh kerusakan awal. Inflamasi yang berlangsung lama (kronik) menyebabkan peralihan sel yang masuk ke area inflamasi, yaitu dari sel PMN (polimorfonuklear) menjadi sel mononuklear (makrofag, limfosit dan sel plasma). ${ }^{22}$

Pada penelitian sebelumnya 
diungkapkan bahwa asap obat nyamuk bakar lebih berbahaya dibandingkan asap rokok karena memiliki particulate matter 75-135 kali asap rokok. ${ }^{11}$ Pada penelitian ini, laring tikus wistar kelompok perlakuan asap obat nyamuk (kelompok III) secara kualitatif, terlihat lebih banyak sel-sel radang dibandingkan dengan kelompok perlakuan asap rokok (kelompok II). Namun demikian, metaplasia yang terjadi lebih banyak pada kelompok perlakuan asap rokok dibandingkan dengan kelompok perlakuan asap obat nyamuk. Jika dilihat secara menyeluruh, dari perubahan morfologik epitel dan keadaan inflamasi, dapat dikatakan bahwa kelompok perlakuan asap obat nyamuk menunjukkan respon patologis yang lebih jelek dibandingkan dengan kelompok perlakuan asap rokok.

Dibandingkan dengan kedua kelompok perlakuan yang lain (kelompok II dan III), gambaran mikroskopis laring tikus wistar kelompok perlakuan asap kendaraan bermotor (kelompok IV) memiliki sel-sel radang yang lebih banyak. Hal ini tidak mendukung pernyataan penelitian sebelumnya yang mengatakan bahwa asap rokok lebih berbahaya dibandingkan dengan asap kendaraan bermotor karena memproduksi 10 kali lebih banyak emisi particulate matter. ${ }^{12}$ Hal ini kemungkinan diakibatkan oleh flow rate (kecepatan aliran) dari dari asap rokok lebih rendah dari flow rate asap kendaraan bermotor, sehingga walaupun asap rokok memiliki particulate matter yang lebih banyak, asap kendaraan bermotor lebih banyak terhirup dibandingkan dengan asap rokok. ${ }^{23,24}$ Namun jika dilihat dari banyaknya sel epitel dari lapisan epitel mukosa laring yang mengalami metaplasia, kelompok perlakuan asap rokok masih terlihat lebih banyak sel metaplasia kolumnar dibandingkan kelompok perlakuan asap kendaraan bermotor. Jika dibandingkan dengan kelompok perlakuan asap obat nyamuk, kelompok perlakuan asap kendaraan bermotor terlihat mengandung sel epitel metaplasia yang relatif lebih banyak dari kelompok perlakuan asap obat nyamuk.

Berdasarkan hasil penelitian ini, secara umum dapat dikatakan bahwa kelompok perlakuan asap kendaraan bermotor menunjukkan reaksi patologik laring yang paling jelek, diikuti oleh kelompok perlakuan asap obat nyamuk dan kelompok perlakuan asap rokok.

Penelitian ini telah memberikan hasil yang dapat menambah informasi dan pengetahuan serta pembuktian teori mengenai efek negatif polutan-polutan di udara terhadap kesehatan saluran pernapasan terutama saluran pernapasan atas. Namun penelitian ini masih memiliki beberapa kekurangan dan keterbatasan, salah satunya yaitu kuantitas paparan yang diberikan pada setiap subjek penelitian tidak diukur secara akurat sehingga mengurangi keakuratan hasil yang didapatkan. Pengukuran particulate matter dan karbon monoksida dapat menggunakan real-time aerosol monitor dan CO monitor, distribusi partikel juga dapat diukur dengan alat yang dinamakan cascade impactor. ${ }^{25}$

Perlu juga dilakukan penelitian dengan jangka waktu yang bervariasi untuk mengetahui perbandingan respon akut dan kronik dari laring maupun bagian saluran pernapasan yang lain.

\section{SIMPULAN}

1. Gambaran histopatologik laring tikus wistar yang dipapar asap rokok, asap obat nyamuk bakar dan asap kendaraan bermotor selama 2 jam per hari dalam jangka waktu 30 hari menunjukkan metaplasia lapisan epitel mukosa laring dan inflamasi kronik dengan gradasi yang berbeda.

2. Gambaran histopatologik laring tikus wistar yang dipapar asap kendaraan bermotor menunjukkan perubahan histopatologik yang paling jelek diikuti gambaran histopatologik asap obat nyamuk bakar dan asap rokok

\section{SARAN}

1. Perlu dilakukan pengukuran akurat kuantitas paparan yang diberikan kepada setiap subjek 
2. Perlu dilakukan penelitian lanjut dengan waktu yang bervariasi untuk mengetahui perbandingan respon akut dan kronik dari laring maupun bagian saluran pernapasan yang lain

\section{DAFTAR PUSTAKA}

1. Vallero D.Fundamentals of Air Pollution (4th ed). Durham: AP, 2008; p. 3.

2. Maitra A. Penyakit Lingkungan. In: Asroruddin $\mathrm{M}$, Hartanto $\mathrm{H}$, Darmaniah N, editors. Buku Ajar Patologi Robbins (7th ed). Jakarta: EGC, 2007; p. 298, 303.

3. National Institute of Environment Health Sciences. Air Pollution [Internet]. Health and Education. 2015 Sep 7 [cited 3 October 2015].

Available from:

http://www.niehs.nih.gov/health/topic

s/agents/air-pollution/index.cfm.

4. World Health Organization. Prevalence of tobacco use [Internet]. 2015 [cited 3 October 2015].

Available from: http://www.who.int/ gho/tobacco/use/en/.

5. Bruce N, Perez-Padilla R, Albalak $\mathbf{R}$. Indoor air pollution in developing countries: a major environmental and public health challenge. Bull World Health Organ. 2000;78(9):1078-92.

6. Flo-Neyret C, Lorenzi-Filho G, Macchione M, Garcia MLB, Saldiva PHN. Effects of formaldehyde on the frog's mucociliary epithelium as a surrogate to evaluate air pollution effects on the respiratory epithelium. Braz J Med Biol Res. 2001;34(5):63943.

7. Mulla MS, Thavara U, Tawatsin A, Kong-Ngamsuk W, Chompoosri J. Mosquito burden and impact on the poor: measures and costs for personal protection in some communities in Thailand. J Am Mosq Control Assoc. 2001;17(3):153-9.

8. Audi of America, Inc. Motor Vehicle Exhaust Emission. Auburn Hills: Audi Academy; 2001.

9. Raub JA, Mathieu-Nolf M, Hampson NB, Thom SR. Carbon monoxide poisoning - a public health perspective. Toxicology. 2000;149(1):1-14.

10.OICA. World Vehicle in Use - All Vehicles [Internet]. 2013 [cited 3 October 2015].
Available

from:

http://www.oica.net/category/vehiclesin-use/.

11.Liu W, Zhang J, Hashim JH, Jalaludin J, Hashim Z, Goldstein BD. Mosquito coil emissions and health implications. EHP. 2003; 111(12): 1454-60.

12.Ivernizzi G, Ruprecht A, Mazza R, Rosseti E, Sasco A, Boffi R. Particulate matter from tobacco versus diesel car exhaust: an educational perspective. Tob Control. 2004;13:21921.

13.Tamashiro E, Cohen N, Palmer J, Lima $\mathbf{W}$. Effects of cigarette smoking on the respiratory epithelium and its role in the pathogenesis of chronic rhinosinusitis. Braz J otorhinolaryngol. 2009;75(6):903-7.

14.Phillip Morris International Management SA. What is in Cigarette Smoke? [Internet]. Justthefacts. 2015 Oct [cited 14 October 2015]. Available from: http://www.pmi.com/eng/our_products/ whats_in_smoke/pages/whats_in_smok e.aspx\#.

15.JTI. Tar, nicotine and carbon monoxide (TNCO) pack prints. Smoking and Health. 2012 Mar 26 [cited 29 October 2015]. Available from: http://www.jti.com/how-we-dobusiness/smoking-and-health/tarnicotine-and-carbon-monoxide-packprints/.

16.Lukwa N, Chandiwana SK. Efficacy of mosquito coils containing $0.3 \%$ and 0.4\% pyrethrins against An.gambiae sensu lato mosquitoes. Cent Afr Med. 1998;44(4):104-7.

17.Extraordinary Road Trip. Vehicles and the Emissions They Produce. Research Lab. 2015 Feb 21 [cited 6 October 2015]. Available from:http://www.extraordinaryroadtrip. org/research-library/airpollution/vehicleemissions/combustion.asp

18.Devi RS. Effects of mosquito coil on the developing chick embryo. WJPR. 2014;3(5):991-1001.

19.Sydbom A, Blomberg A, Parnia S, Stenfors N, Sandstorm T, Dahlen SE. Health effects of diesel exhaust emissions. European Respiratory Journal. 2001;17(4):733-46. 
20.Treuting P, Dintzis S. Comparative Anatomy and Histology: A Mouse and Human Atlas. 1st ed. London:AP;2012. p. 88-90.

21.Mitchell RN, Cotran RS. Jejas, Adaptasi, dan Kematian Sel. In: Asroruddin M, Hartanto H, Darmaniah N. Buku Ajar Patologi Robbins. 7th ed. Jakarta: EGC; 2007. p. 15

22.Mitchell RN, Cotran RS. Inflamasi Akut dan Kronik. In: Asroruddin M, Hartanto H, Darmaniah N. Buku Ajar Patologi Robbins. 7th ed. Jakarta: EGC; 2007. p. 35, 56

23.Chase RE, Maricq MM, Kaiser EW, Podsiadlik DH, Siegl WO. The Effect of Dimethoxy Methane Fuel Additive on Particle Emissions from a Light Duty Diesel Vehicle. In: Song C, Hsu CS, Mochida I. Chemistry of Diesel Fuels. 1st ed. New York: Taylor and Francis;2000. p. 214

24.Sahu SK, Tiwari M, Bhangare RC, Pandit GG. Particle Size Distribution of Mainstream and Exhaled Cigarette Smoke and Predictive Deposition in Human Respiratory Tract. Aerosol and Air Quality Research. 2013;13:324-32.

25.Tsuji H, Fujimoto H, Matsuura D, Nishino T, Lee KM, Yoshimura $H$. Comparison of Biological Responses in Rats Under Various Cigarette Smoke Exposure Conditions. J Toxicol Pathol. 2013;26(2):159-74. 